\title{
Evaluation of Forage Type Barley Varieties for Forage Yield and Nutritive Value in the Peace Region of Alberta
}

\author{
Kabal S. Gill ${ }^{1}$, Akim T. Omokanye ${ }^{2}$, J.P. Pettyjohn ${ }^{1} \&$ Meghan Elsen $^{3}$ \\ ${ }^{1}$ Smoky Applied Research \& Demonstration Association, 701 Main Street, Falher, Alberta T0H 1M0, Canada \\ ${ }^{2}$ Peace Country Beef \& Forage Association, Animal Science Building, Grande Prairie Regional College, , \\ Fairview, Alberta, Canada \\ ${ }^{3}$ Lakeland Agricultural Research Association, Box 7068, Bonnyville, Alberta T9N 2H4, Canada \\ Correspondence: Kabal S. Gill, Smoky Applied Research \& Demonstration Association, 701 Main Street, Falher, \\ Alberta T0H 1M0, Canada. Tel: 1-780-837-2900. E-mail: gillsarda@serbernet.com
}

Received: November 7, 2012 Accepted: December 6, 2012 Online Published: January 15, 2013

doi:10.5539/jas.v5n2p24

URL: http://dx.doi.org/10.5539/jas.v5n2p24

\begin{abstract}
There is increasing use of barley (Hordeum vulgare L.) forage for swath grazing, bale grazing and silage for back grounding and finishing beef cattle in western Canada. Twelve barley varieties ( 6 two row and 6 six row) were compared in field trials in the Peace Region of Alberta, from 2009 to 2011, to identify the varieties with superior forage yield and nutritive value. Forage yield dry matter (DM) yield was greatest for Busby, followed by Ponoka, CDC Cowboy, Seebe, CDC Austenson, Vivar, Chigwell, Sundre, Xena, Trochu, AC Lacombe, and AC Ranger. Eight varieties had $>8.0 \mathrm{t} \mathrm{ha}^{-1} \mathrm{DM}$ yield, five of which belonged to the two-row barley. The crude protein $(\mathrm{CP})$ content varied from $8.70 \%$ for Busby to $10.4 \%$ for Seebe. Based on high CP content and low detergent fiber contents, CDC Austenson, Chigwell and Ponoka were the top three varieties. Two of the top three varieties for both forage yield and nutritive value were the two-row type, an indication that the two-row barley type may be better adapted for forage production in this environment. The top rated varieties may therefore be chosen for silage, green feed or swath grazing system in the Peace Region environs.
\end{abstract}

Keywords: barley, forage yield, nutritive value, Peace region, six-row, two-row, varieties

\section{Introduction}

Feed accounts for a greater portion of the total costs for beef cattle production in Alberta. A major portion of these costs comes from confined feeding in late fall and winter, which can last for six to seven months. In order to reduce winter feed costs, beef cattle producers have always explored other options.

The use of barley forage is increasing in western Canada, particularly for swath grazing, bale grazing and silage for back grounding and finishing beef cattle (Baron et al., 2012; Entz et al., 2002; McCartney \& Vaage, 1994; McCartney et al., $2004 \& 2008$ ). Swath grazing can reduce costs of winter feeding programs for beef cows by $40 \%$, due to elimination of harvesting, hauling, and feeding costs as well as reducing manure spreading costs (McCartney et al., 2004).

In Alberta, barley and oat (Avena sativa L) are the major forage crops, although significant acreage of mixed grains, spring wheat (Triticum aestivum L.) and triticale (Triticale hexaploide Lart.) are also harvested as forages (Alberta Agriculture and Rural Development, 2012). Barley is higher in CP than oat, triticale and spring wheat (Cherney \& Marten, 1982). Similarly, barley has superior forage quality of small grain species tested (Baron et al., 2000). Barley varieties are generally classified as two rows or six rows, as feed grain or malting, as covered or hulless; and these are used for animal feed as grain, whole plant (hay, silage or green feed) or straw (Alberta Barley Commission, 2008). Feed varieties occupy about half of Alberta's total barley acreage, and usually have higher yields and better agronomic characteristics (disease resistance, lodging resistance, shattering resistance, etc.) than most malt varieties (Alberta Agriculture and Rural Development, 2010a). Forage barley varieties produce high total biomass (whole plant harvest) but likely have insufficient seed yield to compete with regular varieties when only grain production is desired. The provincial total harvested area in 2009 for green feed was 1.24 million acres, while silage acreage was 0.945 million acres (Alberta Agriculture and Rural Development, 2010b). 
Considering the protein, digestibility, detergent fiber, relative feed value for ruminant animals, Waldo and Jorgensen (1981), and Linn and Martin (1989) stated high-quality forage must have high intake, digestibility, and efficiency of utilization. Though numerous agronomic studies have been conducted on the suitability and production potential of annual crops in livestock production systems in Alberta (Aasen et al., 2004; Baron et al., 2012; McCartney \& Vaage, 1994; McCartney et al., 2004; 2008), only a few studies on the suitability of barley in the beef cattle production systems have been conducted in the Peace Region. The objective of this study was to identify barley varieties with superior yield and nutritive value for beef cattle production in the Peace Region of Alberta.

\section{Method}

\subsection{Experimental Sites}

Field experiments were conducted during three seasons on farmer's field near High Prairie (2009 and 2011; $55^{\circ} 26^{\prime} \mathrm{N}, 116^{\circ} 29^{\prime} \mathrm{E} ; 732 \mathrm{~m}$ above sea level; Legal land location NW25-74-17W5) and Valleyview (2010; 55 $04^{\prime}$ $\mathrm{N}, 117^{\circ} 17^{\prime} \mathrm{W}$; $762 \mathrm{~m}$ above sea level; Legal land location SW28-70-21W5), in the Peace Region of Alberta, Canada. Both sites have a subarctic climate (also called boreal climate), which is characterized by long, usually very cold winters, and short, cool to mild summers. Monthly weather data for 2009-2011 as well as the long term (30 years) averages of the spring soil moisture (SSM), rainfall, maximum and minimum temperatures and growing degree days are given in Table 1.

Table 1. Spring soil moisture (SSM), rainfall, and air temperature in the crop growing months for different years and long-term averages (LTA); and long-term monthly averages of growing degree days

\begin{tabular}{|c|c|c|c|c|c|}
\hline Year & $\mathrm{SSM}, \mathrm{mm}$ & May & June & July & Total \\
\hline & \multicolumn{5}{|c|}{ Rainfall, mm } \\
\hline 2009 & 100 & 33 & 9 & 92 & 234 \\
\hline 2010 & 37 & 36 & 17 & 42 & 152 \\
\hline 2011 & 35 & 38 & 166 & 83 & 322 \\
\hline \multirow[t]{2}{*}{ LTA - Both sites } & 91 & 42 & 84 & 83 & 303 \\
\hline & \multicolumn{5}{|c|}{ Maximum temperature, ${ }^{\circ} \mathrm{C}$} \\
\hline 2009 & & 23.6 & 27.9 & 29.1 & \\
\hline 2010 & & 26.1 & 27.7 & 29.3 & \\
\hline 2011 & & 25.4 & 25.2 & 24.9 & \\
\hline LTA-High Prairie & & 16.5 & 19.4 & 21.1 & \\
\hline \multirow[t]{2}{*}{ LTA-Valleyview } & & 17.0 & 20.4 & 22.2 & \\
\hline & \multicolumn{5}{|c|}{ Minimum temperature, ${ }^{\circ} \mathrm{C}$} \\
\hline 2009 & & -17.5 & -2 & 1.9 & \\
\hline 2010 & & -7.9 & -1.1 & 3.7 & \\
\hline 2011 & & -1.9 & -0.9 & 5.2 & \\
\hline LTA -High Prairie & & 4.1 & 7.9 & 8.9 & \\
\hline \multirow[t]{2}{*}{ LTA -Valleyview } & & 3.8 & 8.1 & 9.9 & \\
\hline & \multicolumn{5}{|c|}{ Long-term growing degree days } \\
\hline High Prairie & & 174 & 260 & 325 & \\
\hline Valleyview & & 173 & 278 & 343 & \\
\hline
\end{tabular}

Soil at High Prairie site is an Ortho Humic Gleysol, with dark colour, sandy to clay loam texture, and high productivity (Soil Classification Working Group, 1998). Soil at Valleyview is a Grey Luvisol with loam to clay loam, texture and medium productivity. Some soil properties are given in Table 2. Methods used were loss on ignition for organic matter; water extraction for $\mathrm{pH}$; Mehlich No. 3 extraction (EPA6010) followed by analyses using ICP-OES for P, K, Mg, and Ca (Soil and Plant Analysis Council, 1999). Nitrate-N was determined using 
$0.01 \mathrm{M} \mathrm{K}_{2} \mathrm{SO}_{4}$ extraction and extract analysed colour metrically (Standard Methods for the Examination of Water and Wastewater. 22nd Edition 4500- $\mathrm{NO}_{3}$; Automated Cadmium Reduction Method).

Table 2. Soil properties at the experimental sites*

\begin{tabular}{ccccccccc}
\hline Site & $\begin{array}{c}\mathrm{OM}^{\mathrm{z}} \\
\%\end{array}$ & $\begin{array}{c}\mathrm{pH} \\
\text { (Water) }\end{array}$ & $\begin{array}{c}\mathrm{CECy} \\
\mathrm{Meq} / 100 \mathrm{~g}\end{array}$ & $\begin{array}{c}\text { Bray 1-Px } \\
\mathrm{ppm}\end{array}$ & $\begin{array}{c}\mathrm{K} \\
\mathrm{ppm}\end{array}$ & $\begin{array}{c}\mathrm{Ca} \\
\mathrm{ppm}\end{array}$ & $\begin{array}{c}\mathrm{Mg} \\
\mathrm{ppm}\end{array}$ & $\begin{array}{c}\mathrm{NO3-N} \\
\mathrm{ppm}\end{array}$ \\
\hline High Prairie & 7.4 & 6.4 & 22.4 & 12.0 & 165 & 2990 & 675 & 17.0 \\
Valleyview & 6.3 & 5.5 & 17.2 & 21.0 & 185 & 1350 & 295 & 43.0 \\
\hline
\end{tabular}

*Soil texture at both sites was clay loam.

z, OM, organic matter.

y, CEC, cation exchange capacity.

, Bray 1-P, Bray-1 method of P test.

\subsection{Experimental Design, Plant Material, Seeding and Crop Management}

The treatments consisted of twelve barley varieties, 6 two-row and 6 six-row. Their brief description (by Agriculture and Agri-Food Canada \& Alberta Agriculture and Rural Development, 2011) is given below:

Two-row barley varieties-

1) Busby- feed barley, rough awned

2) CDC Austenson-rough awn variety, high feed yield

3) CDC Cowboy-forage barley

4) Ponoka - feed barley for grain or silage

5) Seebe - feed barley for silage

6) Xena - semi-smooth awns (used as check variety for 2-row barley)

Six-row barley varieties-

7) AC Lacombe-feed barley, smooth awn

8) AC Ranger-feed barley, smooth awns

9) Chigwell - feed barley, smooth awns

10) Sundre - feed barley for grain and forage

11) Trochu - feed barley for silage, smooth awn

12) Vivar-feed barley (used as check variety for 6-row barley)

Soil tests for the top $0-15 \mathrm{~cm}$ were conducted prior to seeding (Table 2). The treatments were arranged in a randomized complete block design with four replications. Plot size was $10 \mathrm{~m}$ long 6 rows at $23 \mathrm{~cm}$ spacing between rows. Seeding rate was 250 live seeds $\mathrm{m}^{-2}$. Seeding rate $\left(\mathrm{kg} \mathrm{ha}^{-1}\right)$ for each variety was determined using the formula: 1000 kernel weight $\mathrm{x}$ (desired seeds $\left.\mathrm{m}^{-2} / 1000\right) \mathrm{x}$ plot area in $\mathrm{m}^{2} \mathrm{x}(100 / \%$ germination) $\mathrm{x} 1.05$. The factor 1.05 was used in the seed rate calculations to compensate for $5 \%$ seeds not emerging.

In each year, the site had been harrowed before seeding. Each year, prior to seeding, a pre-seed weed control was carried out with glyphosate. A Fabro plot drill equipped with Atom jet openers was used to seed on May 16 in 2009, May 16 in 2010 and May 20 in 2011. All plots were fertilized with $95 \mathrm{~kg} \mathrm{ha}^{-1}$ of 11-52-0 (seed placed) plus $111 \mathrm{~kg} \mathrm{ha}^{-1}$ of 0-0-60, and $145 \mathrm{~kg} \mathrm{ha}^{-1}$ of 46-0-0 (side banded) in 2009; $43 \mathrm{~kg} \mathrm{ha}^{-1}$ of 11-52-0 (seed placed) plus $28 \mathrm{~kg} \mathrm{ha}^{-1}$ of 0-0-60, and $136 \mathrm{~kg} \mathrm{ha}^{-1}$ of 46-0-0 (side banded) in 2010; $65 \mathrm{~kg} \mathrm{ha}^{-1}$ of 11-52-0 (seed placed) plus 37 $\mathrm{kg} \mathrm{ha}^{-1}$ of 0-0-60, $46 \mathrm{~kg} \mathrm{ha}^{-1}$ of 46-0-0 and $140 \mathrm{~kg} \mathrm{ha}^{-1}$ of 20-0-0-24 (side banded) in 2011. In crop spraying of $0.44 \mathrm{~L} /$ ha Prestige A $+1.98 \mathrm{~L} /$ ha Prestige B was carried out in 2011 only. 


\subsection{Measurements}

\subsubsection{Crop Growth and Forage Yield}

Plant stand was visually inspected in all plots to assess adequacy of crop emergence. Prior to harvest, plant heights at random were measured from 3 plants and notes were also taken on plant lodging.

Harvesting for forage yield was done at the soft dough stage. Cereal crops, ensiled at the soft dough stage, have high yield and are reliable source of conserved forage for over wintering cattle in Western Canada (McCartney \& Vaage, 1994). The plots were assessed to estimate any major part of rows without plants to determine the actual harvest area per plot. The above ground parts of plants were harvested on July 31 in 2009, July 28 in 2010 and August 5 in 2011. For each plot, four $6 \mathrm{~m}$ long inner rows were harvested and weighed fresh. About $0.5 \mathrm{~kg}$ sub-sample was oven-dried at $50^{\circ} \mathrm{C}$ to constant weight for forage dry matter (DM) yield estimation.

\subsubsection{Nutritive Value}

The forage nutritive value (based on $\%$ dry matter bases) was determined using two dry composite forage samples per treatment, one for replications $1 \& 2$, and the other for replications $3 \& 4$. These samples were sent to a commercial laboratory for nutritive value using standard laboratory procedures for wet chemistry analysis as follows. Nitrogen content was measured by Dumas Method (dried, ground tissue combusted with oxygen and analysed by thermal conductivity). For the $\mathrm{P}, \mathrm{K}, \mathrm{Ca}, \mathrm{Mg}$, and $\mathrm{Na}$ contents, dried ground tissue was digested with aqua regia on a hot block digester and the digest analysed by ICP-OES (Western States Laboratory Proficiency Testing Program, 1997).

Laboratory reported values included crude protein (CP), acid detergent fiber (ADF), neutral detergent fiber (NDF), minerals $(\mathrm{Ca}, \mathrm{P}, \mathrm{K}, \mathrm{Mg} \& \mathrm{Na})$, total digestible nutrients $(\mathrm{TDN})$, net energy for gain $\left(\mathrm{NE}_{\mathrm{G}}\right)$ and maintenance $\left(\mathrm{NE}_{\mathrm{M}}\right)$, and relative feed value $(\mathrm{RFV})$.

The following variables were calculated from the measured laboratory parameters:

$$
\text { Crude protein yield }\left(\mathrm{CPY}, \mathrm{kg} \mathrm{CP} \mathrm{ha}^{-1}\right)=\mathrm{CP} \times \mathrm{DM}
$$

Digestible feed energy (DFE, MCal kg$\left.{ }^{-1}\right)=4.4 \times(\mathrm{TDN} / 100)($ Bull, 1981)

Digestible crude protein $(\mathrm{DCP}, \% \mathrm{DM})=0.929 \mathrm{CP}-3.52$ (Dermarguilly \& Weiss, 1970)

Dry matter intake (DMI, \% of body weight) $=120 / \mathrm{NDF}$ (Undersander \& Moore, 2002)

Dry matter digestibility $(\mathrm{DDM}, \% \mathrm{DM})=88.9-0.779 \mathrm{ADF}$ (Undersander \& Moore, 2002)

$$
\text { Relative feed value }(\mathrm{RFV})=(\mathrm{DDM} \times \mathrm{DMI}) / 1.29
$$

\subsection{Data Analyses}

The data for each of the agronomic and forage quality parameters were subjected to analysis of variance (ANOVA) as a split-plot design, with years as main plot effects and the barley varieties as sub-plots, using the GLM procedure (SAS, 1990). Where ANOVA indicated significant treatment effects, the means were separated by the least significant difference (LSD) at the 0.05 probability level. Significant differences in the text refer to $P<0.05$. The ANOVA for most measured parameters, including forage DM yield indicated no treatment $\times$ year interaction. Therefore, the reported values are means of the 3 years for the barley varieties and means of the 12 barley varieties for the years. Pearson's correlation coefficient (r) between plant height and forage DM yields was also calculated.

\section{Results}

\subsection{Weather Observations during the Growing Seasons}

The water supply, from the spring soil moisture plus rain during the growing season, was below normal in 2009 and 2010 while it was near normal in 2011 (Table 1). During the three growing seasons, maximum temperatures were between 23.6 and $29.3^{\circ} \mathrm{C}$, but May 2009 had much lower minimum temperature $\left(-17.5^{\circ} \mathrm{C}\right)$ than in other years.

\subsection{Plant Growth, Moisture Content and Forage Yield}

Plant height was significantly affected by varieties (Table 3). With the exception of Busby, CDC Cowboy grew significantly taller than other varieties. Five of the twelve varieties had $<80.0 \mathrm{~cm}$ height. Plant height was affected by trial years, with barley growing tallest in 2011 followed by 2009 and then by 2010 . There was no lodging observed during any of the years. 
Table 3. The moisture content, plant height, dry matter (DM) yield, crude protein (CP) content and crude protein yield (CPY) of forage for the barley varieties and years in the Peace Region of Alberta

\begin{tabular}{|c|c|c|c|c|c|}
\hline Variety/Year & Moisture \% & Height $\mathrm{cm}$ & DM kg ha ${ }^{-1}$ & $\mathrm{CP} \%$ & CPY kg ha ${ }^{-1}$ \\
\hline & \multicolumn{5}{|c|}{ Means across the $2009-2011$ years } \\
\hline \multicolumn{6}{|l|}{ Two row barley } \\
\hline Busby & 69.6 & 95.8 & 9423 & 8.70 & 820 \\
\hline CDC Austenson & 66.9 & 77.8 & 8186 & 10.20 & 835 \\
\hline CDC Cowboy & 69.5 & 100.7 & 8277 & 9.39 & 777 \\
\hline Ponoka & 68.7 & 77.2 & 8674 & 9.27 & 804 \\
\hline Seebe & 68.9 & 85.7 & 8232 & 10.40 & 856 \\
\hline Xena & 66.9 & 77.9 & 7899 & 9.72 & 768 \\
\hline \multicolumn{6}{|l|}{ Six row barley } \\
\hline AC Lacombe & 68.2 & 84.9 & 7392 & 9.34 & 687 \\
\hline AC Ranger & 68.9 & 79.8 & 7195 & 9.53 & 686 \\
\hline Chigwell & 66.2 & 85.1 & 8023 & 10.10 & 810 \\
\hline Sundre & 68.6 & 90.4 & 8001 & 9.13 & 730 \\
\hline Trochu & 68.3 & 81.8 & 7802 & 9.64 & 752 \\
\hline Vivar & 68.7 & 77.3 & 8061 & 10.20 & 822 \\
\hline Variety $\mathrm{LSD}_{0.05}$ & 2.52 & 6.61 & 950 & 1.310 & 204 \\
\hline \multirow[t]{2}{*}{ Variety significance } & $*$ & $* * *$ & $* * *$ & $\mathrm{NS}^{\mathrm{z}}$ & $\mathrm{NS}^{\mathrm{z}}$ \\
\hline & \multicolumn{5}{|c|}{ Means across the 12 barley varieties } \\
\hline 2009 & 72.6 & 85.7 & 7268 & 8.99 & 639 \\
\hline 2010 & 63.2 & 63.0 & 5968 & 11.8 & 727 \\
\hline 2011 & 69.6 & 102.9 & 10843 & 8.2 & 871 \\
\hline Year $\operatorname{LSD}_{0.05}$ & 2.15 & 5.98 & 278 & 1.07 & 166 \\
\hline Year significance & $* * *$ & $* * *$ & $* * *$ & $* * *$ & $* * *$ \\
\hline Overall Mean & 68.3 & 84.4 & 8050 & 9.63 & 779 \\
\hline Coefficient of variation, $\%$ & 2.6 & 5.6 & $8.4-1$ & 7.5 & 14.9 \\
\hline
\end{tabular}

${ }^{\mathrm{z}} \mathrm{LSD}$, least significant difference.

*, and *** refers to $\mathrm{P}<0.05$ and $\mathrm{P}<0.001$ respectively.

NS, not significant at $\mathrm{P}<0.05$.

Forage moisture content at harvest was significantly affected by varieties (Table 3). Most varieties had similar moisture content at harvest. But CDC Austenson, Xena and Chigwell had lower moisture content in comparison with other varieties. Busby and CDC Cowboy had significantly higher moisture content than CDC Austenson, Xena and Chigwell. Also Chigwell had higher moisture content than Seebe and AC Ranger. Moisture content was different between years, and this was in the order of $2009>2011>2010$.

The DM yield was significantly influenced by varieties (Table 3). With the exception of Ponoka, Busby had significantly higher DM yield than other varieties. Ponoka, CDC Cowboy and Seebe also had greater DM yields than both AC Lacombe and AC Ranger. Eight of the twelve varieties had $>8.0 \mathrm{t} \mathrm{ha}^{-1} \mathrm{DM}$ yield, five of which belonged to the two-row barley. The DM yields were significantly different between years, and the order was $2011>2009>2010$.

The Pearson's correlation between plant heights and DM yields of the varieties was very strong and significant $(\mathrm{r}=0.83, P=0.0001, \mathrm{n}=142)$. 


\subsection{Forage Nutritive Value}

\subsubsection{Crude Protein Content (CP) and Yield (CPY)}

Both CP content and CPY were not significantly influenced by varieties (Table 3). The CP content varied from $8.70 \%$ for Busby to $10.4 \%$ for Seebe. The calculated CP yield varied from 686 to $856 \mathrm{~kg} \mathrm{CP} / \mathrm{ha}$. However, both $\mathrm{CP}$ content and CPY were significantly influenced by year. The order of CP content with respect to trial years was $2010>2009>2011$. The CPY was significantly higher in 2011 than 2009 and 2010. Both 2009 and 2010 had similar CPYs.

\subsubsection{Minerals}

The measured forage $\mathrm{Ca}$ and $\mathrm{P}$ contents and the resulting $\mathrm{Ca}: \mathrm{P}$ ratios were all significantly influenced by barley varieties (Table 4). Forage Ca content was highest for AC Lacombe $(0.48 \%)$ and lowest for both CDC Austenson and Xena $(0.33 \%)$. All the six-row varieties had $\geq 0.40 \% \mathrm{Ca}$ content, while only two of the two-row varieties had $>0.40 \%$ Ca content. Forage P content varied from 0.14 for five varieties (CDC Cowboy, Chigwell, Ponoka, Trochu and Vivar) to $0.16 \%$ for three varieties (AC Ranger, Busby and Seebe). The Ca: P ratios were > 2.0:1.0 for all varieties tested, with most of the six-row varieties giving $\geq 3.0: 1.0$ ratio.

Table 4. The calcium $(\mathrm{Ca})$, phosphorus $(\mathrm{P})$, potassium $(\mathrm{K})$, magnesium $(\mathrm{Mg})$ and sodium $(\mathrm{Na})$ contents; and Ca:P ratios of forage for the barley varieties and years in the Peace Region of Alberta

\begin{tabular}{|c|c|c|c|c|c|c|}
\hline \multirow{2}{*}{ Variety/Year } & $\mathrm{Ca}$ & $P$ & $\mathrm{Ca}: \mathrm{P}$ & $\mathrm{K}$ & $\mathrm{Mg}$ & $\mathrm{Na}$ \\
\hline & $\%$ & $\%$ & Ratio & $\%$ & $\%$ & $\%$ \\
\hline & \multicolumn{6}{|c|}{ Means across the 2009-2011 years } \\
\hline \multicolumn{7}{|l|}{ Two row barley } \\
\hline Busby & 0.43 & 0.17 & 2.64 & 1.43 & 0.13 & 0.09 \\
\hline CDC Austenson & 0.35 & 0.14 & 2.42 & 1.50 & 0.14 & 0.13 \\
\hline CDC Cowboy & 0.37 & 0.14 & 2.81 & 1.58 & 0.14 & 0.12 \\
\hline Ponoka & 0.44 & 0.14 & 3.19 & 1.54 & 0.14 & 0.12 \\
\hline Seebe & 0.38 & 0.16 & 2.50 & 1.62 & 0.14 & 0.11 \\
\hline Xena & 0.33 & 0.15 & 2.24 & 1.42 & 0.13 & 0.10 \\
\hline \multicolumn{7}{|l|}{ Six row barley } \\
\hline AC Lacombe & 0.48 & 0.15 & 3.25 & 1.63 & 0.17 & 0.14 \\
\hline AC Ranger & 0.41 & 0.16 & 2.59 & 1.72 & 0.16 & 0.15 \\
\hline Chigwell & 0.44 & 0.14 & 3.42 & 1.45 & 0.17 & 0.16 \\
\hline Sundre & 0.40 & 0.15 & 2.64 & 1.62 & 0.15 & 0.13 \\
\hline Trochu & 0.42 & 0.14 & 3.13 & 1.69 & 0.15 & 0.18 \\
\hline Vivar & 0.43 & 0.14 & 3.22 & 1.63 & 0.16 & 0.13 \\
\hline Variety $\mathrm{LSD}_{0.05}$ & 0.046 & 0.020 & 0.559 & 0.133 & 0.015 & 0.029 \\
\hline \multirow[t]{2}{*}{ Variety significance } & $* * *$ & $*$ & $*$ & $* * *$ & $* * *$ & $* * *$ \\
\hline & \multicolumn{6}{|c|}{ Means across the 12 barley varieties } \\
\hline 2009 & 0.38 & 0.17 & 2.27 & 1.72 & 0.14 & $\mathrm{NA}^{\mathrm{z}}$ \\
\hline 2010 & 0.37 & 0.13 & 2.89 & 1.57 & 0.17 & 0.19 \\
\hline 2011 & 0.47 & 0.15 & 3.26 & 1.47 & 0.13 & 0.08 \\
\hline Year $\mathrm{LSD}_{0.05}$ & 0.037 & 0.016 & 0.456 & 0.109 & 0.013 & 0.009 \\
\hline Year significance & $* * *$ & $* * *$ & $* * *$ & $* * *$ & $* * *$ & $* * *$ \\
\hline Overall Mean & 0.41 & 0.15 & 2.84 & 1.58 & 0.15 & 0.13 \\
\hline Coefficient of variation, $\%$ & 6.2 & 7.6 & 10.8 & 4.7 & 5.8 & 10.9 \\
\hline
\end{tabular}

${ }^{\mathrm{z}} \mathrm{NA}$, not available.

LSD, least significant difference.

*, and *** refers to $P<0.05$ and $P<0.001$ respectively.

$\mathrm{CV}$, Coefficient of variation. 
Both forage $\mathrm{K}$ and $\mathrm{Mg}$ contents varied among barley varieties, respectively, from 1.41 to $1.72 \%$ and from 0.13 to $0.17 \%$. Generally, the 6-row varieties had higher $\mathrm{K}$ and $\mathrm{Mg}$ content than the 2-row varieties. On a general note, the CDC Austenson and Xena had lower mineral contents $(\mathrm{Ca}, \mathrm{P}, \mathrm{K}$ and $\mathrm{Mg}$ ) and the resulting $\mathrm{Ca}: \mathrm{P}$ ratios than other varieties (Table 4). Forage $\mathrm{Na}$ content was significantly affected by barley varieties. Trochu had significantly higher $\mathrm{Na}$ content than other varieties. For the forage $\mathrm{Na}$ content, the top five varieties belonged to 6-row varieties (Table 4).

The $\mathrm{Ca}, \mathrm{P}, \mathrm{K}, \mathrm{Mg}$ and $\mathrm{Na}$ contents, and $\mathrm{Ca}: \mathrm{P}$ ratios were significantly affected by years. Their orders with respect to years were:

$$
\begin{aligned}
& \mathrm{Ca}-2011>2009>2010 \\
& \mathrm{P}-2009>2011>2010 \\
& \mathrm{Ca}: \mathrm{P}-2011>2010>2009 \\
& \mathrm{~K}-2009>2010>2011 \\
& \mathrm{Mg}-2010>2009>2011 \\
& \mathrm{Na}-2010>2011
\end{aligned}
$$

\begin{tabular}{|c|c|c|c|c|c|}
\hline Variety/Year & $\begin{array}{r}\text { ADF } \\
\% \mathrm{DM}\end{array}$ & $\begin{array}{r}\text { NDF } \\
\% \mathrm{DM}\end{array}$ & $\begin{array}{r}\text { TDN } \\
\% \mathrm{DM}\end{array}$ & $\begin{array}{r}\mathrm{NE}_{\mathrm{G}} \\
\text { Mcal kg }\end{array}$ & $\begin{array}{r}\mathrm{NE}_{\mathrm{M}} \\
\text { Mcal kg }\end{array}$ \\
\hline \multicolumn{6}{|c|}{ Means across the $2009-2011$ years } \\
\hline \multicolumn{6}{|l|}{ Two row barley } \\
\hline Busby & 32.1 & 48.6 & 64.0 & 0.85 & 1.40 \\
\hline CDC Austenson & 28.4 & 44.0 & 66.8 & 1.29 & 1.29 \\
\hline CDC Cowboy & 33.0 & 52.6 & 63.2 & 1.07 & 1.26 \\
\hline Ponoka & 30.1 & 48.1 & 65.1 & 1.12 & 1.31 \\
\hline Seebe & 31.0 & 50.0 & 64.8 & 1.11 & 1.31 \\
\hline Xena & 31.0 & 50.5 & 64.7 & 1.11 & 1.30 \\
\hline \multicolumn{6}{|l|}{ Six row barley } \\
\hline AC Lacombe & 31.1 & 48.9 & 64.7 & 1.11 & 1.30 \\
\hline AC Ranger & 30.6 & 49.4 & 65.1 & 1.21 & 1.31 \\
\hline Chigwell & 29.0 & 44.8 & 66.3 & 1.28 & 1.28 \\
\hline Sundre & 30.9 & 50.0 & 64.8 & 1.11 & 1.30 \\
\hline Trochu & 31.2 & 49.5 & 64.6 & 1.11 & 1.30 \\
\hline Vivar & 32.0 & 50.8 & 64.0 & 1.09 & 1.28 \\
\hline Variety $\mathrm{LSD}_{0.05}$ & 2.62 & 3.65 & 2.04 & 0.06 & 0.07 \\
\hline Variety significance & $\mathrm{NS}^{\mathrm{z}}$ & $*$ & NS & $*$ & NS \\
\hline \multicolumn{6}{|c|}{ Means across the 12 barley varieties } \\
\hline 2009 & 37.2 & 59.7 & 60.0 & 0.74 & 1.29 \\
\hline 2010 & 25.5 & 41.8 & 69.1 & 1.73 & 1.01 \\
\hline 2011 & 30.9 & 47.3 & 64.8 & 0.88 & 1.60 \\
\hline Year $\mathrm{LSD}_{0.05}$ & 2.14 & 2.98 & 1.66 & 0.05 & 0.06 \\
\hline Year significance & $* * *$ & $* * *$ & $* * *$ & $* * *$ & $* * *$ \\
\hline Overall Mean & 31.0 & 49.2 & 64.8 & 1.11 & 1.30 \\
\hline Coefficient of variation, $\%$ & 4.7 & 4.1 & 1.7 & 3.0 & 3.2 \\
\hline
\end{tabular}

\subsubsection{Fiber, Nutrient and Energy Values}

Table 5. The neutral detergent fiber (NDF), acid detergent fiber (ADF), total digestible nutrients (TDN), energy for gain $\left(\mathrm{NE}_{\mathrm{G}}\right)$ and energy for maintenance $\left(\mathrm{NE}_{\mathrm{M}}\right)$ of forage for the barley varieties and years in the Peace Region of Alberta

${ }^{\mathrm{z}} \mathrm{NS}$, not significant at $\mathrm{P}<0.05$.

LSD, least significant difference.

$*, * * * \mathrm{P}<0.05$ and $\mathrm{P}<0.001$ respectively. 
The ADF, TDN and $\mathrm{NE}_{\mathrm{M}}$ indicated no significant $(P>0.05)$ effects of the varieties tested (Table 5). The range of $\mathrm{ADF}$, TDN and $\mathrm{NE}_{\mathrm{M}}$ means, respectively, were 28.4-33.0\%, 63.2-66.8\% and 1.26-1.40\%. But varieties significantly influenced the NDF and $\mathrm{NE}_{\mathrm{G}}$, values. The CDC Austenson and Chigwell had significantly lower $\mathrm{NDF}$ values than other varieties, while they had significantly higher $\mathrm{NE}_{\mathrm{G}}$ values than other varieties. The lowest $\mathrm{NE}_{\mathrm{G}}$ value was from Busby.

Trial years significantly affected $\mathrm{ADF}, \mathrm{NDF}, \mathrm{TDN}, \mathrm{NE}_{\mathrm{G}}$ and $\mathrm{NE}_{\mathrm{M}}$ values. The orders of values with respect to years were:

ADF and NDF-2009 $>2011>2010$

TDN and $\mathrm{NE}_{\mathrm{G}}-2010>2011>2009$

$\mathrm{NE}_{\mathrm{M}}-2011>2009>2010$

3.3.4 Estimated Intake and Digestibility

The digestibility (DFE, DCP and DDM) values showed no significant variety effects (Table 6). The forage intake (DMI) and relative feed value (RFV) on the other hand indicated significant variety effects. With the exception of Chigwell and Ponoka, CDC Austenson had significantly higher DMI value than other varieties. The DMI value was lowest for the CDC Cowboy. The calculated RFV value varied from 116 for CDC Cowboy to 143 for CDC Austenson.

Table 6. The estimated digestible feed energy (DFE), digestible crude protein (DCP), digestible dry matter (DDM), dry matter intake (DMI) and relative feed value (RFV) of forage for the barley varieties and years in the Peace Region of Alberta

\begin{tabular}{|c|c|c|c|c|c|}
\hline Variety/Year & $\begin{array}{c}\text { DFE } \\
\text { Mcal kg }^{-1}\end{array}$ & $\begin{array}{c}\text { DCP } \\
\% \text { DM }\end{array}$ & $\begin{array}{l}\text { DDM } \\
\% \text { DM }\end{array}$ & $\begin{array}{l}\text { DMI } \\
\% \mathrm{DM}\end{array}$ & $\begin{array}{c}\text { RFV } \\
\%\end{array}$ \\
\hline & \multicolumn{5}{|c|}{ Means across the $2009-2011$ years } \\
\hline \multicolumn{6}{|l|}{ Two row barley } \\
\hline Busby & 2.81 & 4.56 & 63.9 & 2.51 & 125 \\
\hline CDC Austenson & 2.94 & 6.00 & 66.8 & 2.75 & 143 \\
\hline CDC Cowboy & 2.78 & 5.20 & 63.2 & 2.34 & 116 \\
\hline Ponoka & 2.86 & 5.09 & 65.1 & 2.56 & 131 \\
\hline Seebe & 2.85 & 6.10 & 64.8 & 2.46 & 124 \\
\hline Xena & 2.85 & 5.51 & 64.7 & 2.47 & 126 \\
\hline \multicolumn{6}{|l|}{ Six row barley } \\
\hline AC Lacombe & 2.85 & 5.15 & 64.7 & 2.49 & 125 \\
\hline AC Ranger & 2.86 & 5.33 & 65.1 & 2.50 & 128 \\
\hline Chigwell & 2.92 & 5.85 & 66.3 & 2.69 & 139 \\
\hline Sundre & 2.85 & 4.96 & 64.9 & 2.45 & 121 \\
\hline Trochu & 2.84 & 5.43 & 64.6 & 2.48 & 125 \\
\hline Vivar & 2.82 & 5.92 & 64.0 & 2.42 & 121 \\
\hline Variety $\mathrm{LSD}_{0.05}$ & 0.09 & 1.22 & 2.04 & 0.19 & 12.1 \\
\hline \multirow[t]{2}{*}{ Variety significance } & $\mathrm{NS}^{\mathrm{z}}$ & NS & NS & * & * \\
\hline & \multicolumn{5}{|c|}{ Means across the 12 barley varieties } \\
\hline 2009 & 2.64 & 4.83 & 60.0 & 2.01 & 94 \\
\hline 2010 & 3.04 & 7.40 & 69.1 & 2.88 & 154 \\
\hline 2011 & 2.85 & 4.10 & 64.8 & 2.55 & 127 \\
\hline Year $\mathrm{LSD}_{0.05}$ & 0.07 & 0.99 & 1.66 & 0.04 & 9.9 \\
\hline Year significance & $* * *$ & $* * *$ & $* * *$ & $* * *$ & $* * *$ \\
\hline Overall Mean & 2.85 & 5.42 & 64.8 & 2.50 & 126 \\
\hline Coefficient of variation, $\%$ & 1.7 & $12 . .4$ & 1.7 & 4.2 & 5.3 \\
\hline
\end{tabular}

${ }^{\mathrm{z}} \mathrm{NS}$, not significant at $\mathrm{P}<0.05$.

LSD, least significant difference.

*, and *** refers to $\mathrm{P}<0.05$ and $\mathrm{P}<0.001$ respectively. 
The DMI, DFE, DCP, DDM and RFV values were significantly affected by trial years. All these parameters were greater in 2010 than in 2009 or 2011, as given below:

DFE $-2010>2011>2009$
DCP $-2010>2009>2011$
DDM $-2010>2011>2009$
DMI $-2010>2011>2009$
RFV $-2010>2011>2009$

\section{Discussion and Implications}

A cereal with adequate amount of energy, crude protein and crude protein yield in forage would be a valuable feed for beef cattle production in the Peace Region of Alberta. It is especially valuable in extending grazing season through swath grazing or in providing high quality green feed or silage for use during the winter months. Forage cereal crops such as barley, oat and triticale all ensile well and are considered suitable silages based on their yield and chemical composition (McCartney \& Vaage, 1993); and their value as green feed, silage or for swath grazing has also been reported (Baron et al., 2012; Entz et al., 2002; McCartney \& Vaage, 1994; McCartney et al., 2004 \& 2008). McCartney and Vaage (1993) emphasized that the economic value of cereal forage for feeding cattle is dependent on both its yield and feeding value (i.e., chemical composition, digestibility and animal performance). The findings from the present study relating to selecting barley varieties for silage, green feed and swath grazing with focus on yield and nutrition in beef cattle production in the Peace Region are discussed below.

Overall, Busby and Ponoka had higher DM yields (Table 3). The two-row barley varieties were the top five DM yielder $\left(\geq 8.2 \mathrm{tha}^{-1}\right)$, an indication that the two-row types (though the differences between the two- and six-row types were not always large) may be more adapted to the Peace Region environs. Generally, the forage DM yields obtained in the present study (e.g. varieties such as Seebe and AC Lacombe) were higher than yields obtained in earlier studies in Alberta and elsewhere in Canada (Nass et al., 1975; Major \& Hamman, 1981; Juskiw et al., 2000; Baron et al., 2012) and recently in Montana, US (Lenssen et al., 2010). The differences in forage DM yields between the present study and earlier studies probably resulted from differences in growing conditions, management practices, and varieties tested. For instance, the studies of Nass et al. (1975) and Juskiw et al. (2000) were done prior to the release of most varieties used in the present study. However, the DM yields obtained in the present study were within the ranges reported by Jefferson and Muri (2009) on annual forages (including barley) at Swift Current, Saskatchewan. The higher mean forage yield obtained in 2011 compared to 2009 and 2011 was due to the higher amount of water availability in 2011 than that of 2009 and 2010 (Table 2).

The significant relationship between plant heights and forage DM yields obtained in the present study for the barley varieties tested, could infer that plant height might be an important agronomic character in breeding and selection for forage barley varieties. Earlier studies, McKenzie et al. (1997) and Baron et al. (1999) reported that taller standard types had a tendency to yield more dry matter under dry land conditions than semi dwarfs, but the differences were not always large. Whether this is the case or not with tested barley varieties warrants further investigation under different agro-climatic conditions.

Considering the protein requirements for beef cows from the second trimester to post calving (NRC, 2000), all barley varieties examined in the present study met the recommended values of 7-9\% CP requirement for pregnant beef cows. But only four (CDC Austenson, Chigwell, Seebe and Vivar) varieties were within the 10-11\% $\mathrm{CP}$ recommended after calving. For varieties that were short of meeting the $\mathrm{CP}$ requirements of lactating cows, the implications will depend on the other feed sources (whether low or high in CP content) being eaten by cattle at the same time. The forage $\mathrm{CP}$ contents obtained in the present study are generally lower than the levels earlier reported by (Baron et al., 2012; Juskiw et al., 1999; McCartney \& Vaage, 1994). The differences could be as a result of differences in soil type, crop management practices and weather.

Crude protein yield (CPY), which is expressed in $\mathrm{kg} \mathrm{ha}^{-1}$, is important to beef cattle producers for determination of winter feed value and in determining supplemental protein feed. Knowledge of this value may be beneficial in the reduction of winter feed costs (USDA-NRCS, 2008). Though varieties in the present study did not have significant differences in CPY (687-856 kg CPY/ha), but the two-row varieties slightly out yielded the six-row varieties by an average difference of $62.2 \mathrm{~kg} \mathrm{CPY} / \mathrm{ha}$.

The major minerals in cattle nutrition are calcium $(\mathrm{Ca})$, phosphorus $(\mathrm{P})$, sodium $(\mathrm{Na})$, chlorine $(\mathrm{Cl})$, magnesium $(\mathrm{Mg})$ and potassium $(\mathrm{K})$. They are required at comparatively high levels in diet as percent or grams per day. The 
varieties evaluated generally had low $\mathrm{P}$ content and none met the $\mathrm{P}$ requirements for the cows that are pregnant or nursing calves. This indicates that some form of mineral $\mathrm{P}$ supplementation may be needed when forage barley is fed to beef cattle. The resulting $\mathrm{Ca}: \mathrm{P}$ ratios obtained for all barley varieties in the present study were generally within the range of $2: 1$ and $7: 1$ suggested for mature beef cows (Alberta Agriculture and Rural Development, 2004). Both the $\mathrm{K}$ and $\mathrm{Mg}$ contents in all the varieties were within the recommended levels for pregnant and nursing cows, and generally within the maximum tolerable concentrations of $3.0 \%$ for $\mathrm{K}$ and $0.4 \%$ for $\mathrm{Mg}$ (NRC, 2000). All varieties exceeded the recommended values of $0.06-0.08 \% \mathrm{Na}$ during gestation period of beef cows and $0.10 \% \mathrm{Na}$ in their early lactating stage, except Busby for the early lactating stage (NRC, 1996). Thus the forage barley varieties examined in the present study had sufficient $\mathrm{Na}$ content.

Energy is probably the most important nutritional consideration in beef cattle production. A range of 55-65\% TDN and 0.90-1.32 Mcal kg. ${ }^{-1} \mathrm{NE}_{\mathrm{M}}$ have been recommended for beef cows (NRC, 2000). The $\mathrm{NE}_{\mathrm{M}}$ is an estimate of the energy value of a feed used to keep an animal in energy equilibrium, i.e., neither gaining nor losing weight. Generally, all barley varieties screened had sufficient amounts of TDN and $\mathrm{NE}_{\mathrm{M}}$ needed for mature beef cattle during pregnancy and nursing of calves. The ability of barley tested varieties to be able to meet beef cows energy requirements is important to cow-calf producers in the Peace Region, particular during winter, as this will mean a substantial savings in feed energy costs.

Fiber (measured by ADF or NDF) in particular is a strong predictor of forage quality, since it is the poorly-digested portion of the cell wall. The ADF values are important because they relate to the ability of an animal to digest the forage. As ADF increases, digestibility of forage usually decreases. The CDC Austenson, which had 28.4\% ADF in the present study, is likely to have better digestibility than CDC Cowboy which had the highest ADF content (33.0\%). The NDF values are important in ration formulation because they reflect the amount of forage the animal can consume. As NDF percentages increase, FDM intake will generally decrease. With the lower NDF values obtained for the CDC Austenson and Chigwell, there may be a tendency that when all the varieties are presented side by side to cows in a preference study both varieties would likely be preferred and consumed more. With its highest value of $33.0 \% \mathrm{ADF}$ and $52.6 \% \mathrm{NDF}, \mathrm{CDC}$ Cowboy would probably be the least consumed by cows. It is important to note that both CDC Austenson and Chigwell consistently had lower ADF and NDF values compared to other varieties.

In terms of estimated DMI, CDC Austenson ranked first followed by Chigwell and then Ponoka. Their superiority in DMI is a reflection of their lower NDF values compared to those of the other varieties. Relative feed value (RFV) provides an indication of the digestibility and how much forage an animal can eat. It's an easy method of ranking a forage and more accurate than using protein content alone as a quality indicator. When forage has a RFV value above 100, it is not necessarily a superior quality forage (Schroeder, 1994). This is because the ADF and NDF values that generate the value of 100 may be relatively high, thus the forage would not be considered any better than average. This is not the case in the present study, because the top three RFV's of 143 (CDC Austenson), 139 (Chigwell) and 131 (Ponoka) all resulted from lower ADF and NDF values when compared to other varieties tested. This therefore indicates superior quality forage of CDC Austenson, Chigwell and Ponoka over other barley varieties examined. According to a quick guide to forage allocation by cattle class (Schroeder, 1996), all varieties far exceeded the suggested RFVs for beef cows (90-115 RFV), and were generally within the ranges suggested for replacement heifers (115-135 RFV) and back grounding stockers (125-150 RFV).

Baron et al. (2000) and Khorasani and Kennelly (1997) found the two-row feed variety to have greater nutritive value than a standard six-row type. In their study, Baron et al. (2000) stated that semi-dwarf barley is the most nutritious, adapted crop for silage production. Two of the three varieties with superior RFV in the present study (CDC Austenson and Ponoka) are two-row and semi-dwarf barley varieties.

Comparing the 2- and 6-row barley varieties across all measured parameters (forage growth and yield, and nutritive indicators) in the present study, it is evident that both two-row and six-row varieties had mean values in the similar range, with only a few exceptions. The only exceptions were with forage DM yield and CP yield. The two-row varieties out yielded the six-row varieties by a mean of $703 \mathrm{~kg} \mathrm{DM} \mathrm{ha}^{-1}$ and $62.2 \mathrm{~kg} \mathrm{CPY} \mathrm{ha}^{-1}$.

\section{Conclusions}

The results from this three-year trial indicate that barley forage is a good option for beef cattle in the Peace Region environs. In term of forage yield, Busby was the best variety, followed by Ponoka and then by CDC Cowboy and Seebe in that order. But based on nutritive value, CDC Austenson, Chigwell and Ponoka were the best all-around in that order -specifically taking into consideration forage $\mathrm{CP}$ content, the tendency to be consumed more and be better digested by beef cows. Five of the six varieties listed above belong to the two-row 
barley type, an indication that the two-row barley type may be better yielding, nutritious and adapted crop for silage production in this environment. Any of these top varieties would therefore be a good alternative to Xena (check for the two-row barley) or Vivar (check for the six-row barley) for silage, green feed or even swath grazing system in the Peace Region environs.

\section{Acknowledgments}

The study was funded by Agricultural Opportunity Fund (AOF) of the Alberta Agriculture and Rural Development (AARD), Alberta beef producers (ABP) and four municipalities (MD's of Big Lakes, Greenview, and Smoky River; and Northern Sunrise County).The technical help by the other SARDA staff is highly appreciated.

\section{References}

Aasen, A., Baron, V. S., Clayton, G. W., Dick, A. C., \& McCartney, D. H. (2004). Swath grazing potential of spring cereals, field pea and mixtures with other species. Canadian Journal of Plant Science, 84, 1051-1058. http://dx.doi.org/10.4141/P03-143

Agriculture and Agri-Food Canada, Alberta Agriculture, Rural Development. (2011). The 2011 Cereal Research Report and other Field Crop Development Centre publications. Retrieved from http://www1.agric.gov.ab.ca/\$Department/deptdocs.nsf/all/fcd5506/\$FILE/2011 cerealresearchreport.pdf

Agriculture and Rural Development. (1992). Effects of Nutrition on Beef Cow Reproduction. Agdex No. FS420/51-1. Retrieved from http://www1.agric.gov.ab.ca/\$department/deptdocs.nsf/all/agdex3527/\$file/420_51-1.pdf? Open Element

Agriculture and Rural Development. (2000). Alberta Feedlot Management Guide. Retrieved from http://www1.agric.gov.ab.ca/\$department/deptdocs.nsf/all/beef4873

Agriculture and Rural Development. (2004). Beef Ration Rules of Thumb. Agdex 420/52-4. Retrieved from http://www1.agric.gov.ab.ca/\$department/deptdocs.nsf/all/agdex9146

Agriculture and Rural Development. (2010a). General Purpose Barley (Hordeum vulgare). Retrieved from http://www.agric.gov.ab.ca/app95/loadCrop?action=display\&id=7

Agriculture and Rural Development. (2010b). Alberta 2009 Crop Season in Review. Retrieved from http://www1.agric.gov.ab.ca/\$department/deptdocs.nsf/all/sdd13100

Agriculture and Rural Development. (2012). Alberta 2011 Green feed and Silage Production Survey Results. Retrieved from http://www1.agric.gov.ab.ca/\$department/ deptdocs.nsf/all/sdd14009.

Alberta Barley Commission. (2008). The potential of barley. Retrieved from $\mathrm{http}: / /$ www.albertabarley.com/barley/feed/feed.html

Baron, V. S., Aasen, A., Oba, M., Dick, A. C., Salmon, D. F., Basarab, J. A., \& Stevenson, C. F. (2012). Swath-Grazing Potential for Small-Grain Species with a Delayed Planting Date. Agronomy Journal, 104, 393-404. http://dx.doi.org/10.2134/agronj2011.0234

Baron, V. S., Okine, E., \& Campbell, A. (2000). Optimizing Yield and Quality of Cereal Silage. Retrieved from http://www1.foragebeef.ca/\$foragebeef/frgebeef.nsf/all/frg70/\$FILE/foragebeef_caoptimizingyieldqualityof cerealsilage.pdf

Baron, V. S., Salmon, D. F., \& McLeod, J. G. (1999). The evaluation of spring and winter triticale lines for forage quality. Retrieved from http://www1.foragebeef.ca/\$foragebeef/frgebeef.nsf/all/frg70/\$FILE/foragebeef_caoptimizingyieldqualityof cerealsilage.pdf

Blunt, K. R. (2001). Seasonal forage dry matter production and quality of 29 dry land grasses in Montana. M.S. Thesis. Montana State University. Bozeman, MT.

Bull, H. S. (1981). Estimating the nutrient value of corn silage. In Proceedings of 1st semi-annual meeting of American Feed manufacturers Association (pp. 15-19). American Feed Manufacturers Assoc., Lexington, KY.

Cherney, J. H., \& Marten, G. C. (1982). Small grain crop forage potential: I. Biochemical determinants of quality and yield. Crop Science, 22, 227-231. http://dx.doi.org/10.2135/cropsci1982.0011183X002200020007x

Demarguilly, C., \& Weiss, P. (1970). Tableau de la valeur alimentaire des fourrages. Paris, INRA. 
Ditsch, D. D., \& Bitzer, M. J. (2005). Managing small grains for livestock forage. Retrieved from http://www.ca.uky.edu/agc/pubs/agr/agr160/agr160.htm

Entz, M. H., Baron, V. S., Carr, P., McCaughey, P. M., Smith, S. R., \& Cash, D. (2002). Potential of forages to diversify Canadian and American northern great plain cropping systems. Agronomy Journal, 94, 240-250. http://dx.doi.org/10.2134/agronj2002.0240

Jefferson, P. G., \& Muri, R. (2009). Annual forage crop yield response to water. Western Beef Development Centre, Humboldt, SK, Canada. Retrieved from http://www.wbdc.sk.ca/pdfs/fact_sheets/2009/2009_\%20Annual\%20Forage\%20Crop\%20Yield \%20Respo nse $\% 20$ to\%20Water.pdf

Juskiw, P. E., Helm, J. H., \& Salmon, D. F. (2000). Forage Yield and Quality for Monocrops and Mixtures of Small Grain Cereals. Crop Science, 40, 138-147. http://dx.doi.org/10.2135/cropsci2000.401138x

Khorasani, G. R., \& Kennelly, J. J. (1997). Optimizing cereal silage quality. Proceedings of the Western Canadian Dairy Seminar, 9, 249.

Kjos, N. P. (1990). Evaluation of the feeding value of fresh forages, silage and hay using near infrared reflectance analysis (NIR). I. A comparison of different methods for predicting the nutritive value. Norwegian Journal of Agricultural Science, 4, 305-320.

Lenssen, A. W., Cash, S. D., Hatfield, P. G., Sainju, U. M., Grey, W. R., Blodgett, S. L., ... Johnson, G. D. (2010). Yield, quality, and water and nitrogen use of durum and annual forages in two-year rotations. Agronomy Journal, 102, 1261-1268. http://dx.doi.org/10.2134/agronj2010.0078

Linn, J. G., \& Martin, N. P. (1999). Forage quality tests and interpretations. Retrievd from http://www.extension.imm.edu/distribution/livestocksystems/D12637.html

Major, D. J., \& Hamman, W. M. (1981). Comparison of sorghum with wheat and barley grown on dry land. Canadian Journal of Plant Science, 61, 37-43. http://dx.doi.org/10.4141/cjps81-006

McCartney, D. H., \& Vaage, A. S. (1994). Comparative yield and feeding value of barley, oat, and triticale silage. Canadian Journal of Animal Science, 74, 91-96. http://dx.doi.org/10.4141/cjas94-014

McCartney, D., Basarab, J. A., Okine, E. K., Baron, V. S., \& Depalme, A. J. (2004). Alternative fall and winter feeding systems for spring calving beef cows. Canadian Journal of Animal Science, 84, 511-522. http://dx.doi.org/10.4141/A03-069

McCartney, D., Fraser, J., \& Ohama, A. (2008). Annual cool season crops for grazing by beef cattle. A Canadian review. Canadian Journal of Animal Science, 88, 517-533. http://dx.doi.org/10.4141/CJAS08052

McKenzie, R. H., Middleton, A., Solberg, E., DeMulder, J., \& Najda, H. (1997). Optimizing barley silage production in Alberta. Alberta Agricultural Research Institute Project 94M608 Final Report. Edmonton, Alberta, Canada.

Nass, H. G., Kuneleius, H. T., \& Suzuki, M. (1975). Effects of nitrogen application on barley, oats and triticale grown as forage. Canadian Journal of Plant Science, 55, 49-53. http://dx.doi.org/10.4141/cjps75-006

Nikkhah, A., Khorasani, G. R., Corbett, R., \& Kennelly, J. J. (1995). In situ DM degradation characteristics of whole crop barley silage (Abstract). Canadian Journal of Animal Science, 75, 648.

NRC (National Research Council). (1996). Nutrient requirements of beef cattle. Seventh Edition. Washington, DC: National Academy Press.

NRC (National Research Council). (2000). Nutrient Requirements of Beef Cattle. Seventh Revised Edition: Update 2000. Washington, DC: The National Academies Press.

SAS Institute, Inc. (1990). SAS user's guide: Statistics (Version 6, 4th ed). SAS Institute Inc., Cary, NC.

Schroeder, J. W. (1994). Interpreting Forage Analysis. North Dakota State University. Retrieved from http://www.ag.ndsu.edu/pubs/plantsci/hay/r1080w.htm

Schroeder, J. W. (1996). Quality Forage for Maximum Production and Return. North Dakota State University. Retrieved from http://www.ag.ndsu.edu/pubs/ansci/range/ as 1117 w.htm

Soil and Plant Analysis Council. (1999). Soil Analysis Handbook of Reference Methods. Soil and Plant Analysis Council, Inc, Athens, GA. 
Soil Classification Working Group. (1998). The Canadian system of soil classification. Agriculture and Agri-Food Canada Publication, 1646 (revised).

Surber, L. M. M., Cash, S. D., Bowman, J. G. P., \& Rolfe, K. M. (2003). Stage of maturity, time of sampling, and method of drying effects on forage quality of Haybet barley. Proceedings of Western Section of American Society of Animal Science, 54, 2003.

Undersander, D., \& Moore, J. E. (2002). Relative forage quality (RFQ) indexing legumes and grasses for forage quality. University of Wisconsin Extension. Retrieved from http://www.uwex.edu/ces/forage/pubs/rfq.htm

USDA-NRCS (Natural Resources Conservation Service). (2008). Total Digestible Nutrients and Protein per Acre Produced by Five Indiangrass Cultivars. Booneville Plant Materials Center, Plant Materials Technical Report CP $512 \quad$ - Pasture \& Hay Planting. Retrieved from http://www.plant-materials.nrcs.usda.gov/pubs/arpmctn8012.pdf

Waldo, D. R., \& Jorgensen, N. A. (1981). Forages for high animal production: Nutritional factors and effects of $\begin{array}{llllll}\text { conservation. Journal of Dairy } & \text { Science, } & 64, & \text { 1207-1229. }\end{array}$ http://dx.doi.org/10.3168/jds.S0022-0302(81)82697-5

Weather Network. (2012). Statistics. Retrieved from http://www.theweathernetwork.com/weather/caab0155

Western States Laboratory Proficiency Testing Program. (1997). Soil and Plant Analysis Methods, version 4 (Inductivity Coupled Plasma Emission Spectroscopy - Method 6001 EPA). 